\title{
Preventive Effects of Spirogyra neglecta and a Polysaccharide Extract against Dextran Sodium Sulfate Induced Colitis in Mice
}

\author{
Sirinya Taya ${ }^{1,2}$, Anna Kakehashi ${ }^{1}$, Rawiwan Wongpoomchai ${ }^{2}$, Min Gi ${ }^{1}$, Naomi \\ Ishii $^{1}$, Hideki Wanibuchi ${ }^{1 *}$
}

\begin{abstract}
Ulcerative colitis (UC) results from colonic epithelial barrier defects and impaired mucosal immune responses. In this study, we aimed to investigate the modifying effects of a Spirogyra neglecta extract (SNE), a polysaccharide extract (PE) and a chloroform fraction (CF) on dextran sodium sulfate (DSS)-induced colitis in mice and to determine the mechanisms. To induce colitis, ICR mice received 3\% DSS in their drinking water for 7 days. Seven days preceding the DSS treatment, oral administration of SNE, PE and CF at doses of 50,25 and $0.25 \mathrm{mg} / \mathrm{kg}$ body weight (low dose), 200,100 and $1 \mathrm{mg} / \mathrm{kg}$ body weight (high dose) and vehicle was started and continued for 14 days. Histologic findings showed that DSS-induced damage of colonic epithelial structure and inflammation was attenuated in mice pre-treated with SNE, PE and CF. Furthermore, SNE and PE significantly protected colonic epithelial cells from DSS-induced cell cycle arrest, while SNE, PE and CF significantly diminished apoptosis. Proteome analysis demonstrated that SNE and PE might ameliorate DSS-induced colitis by inducing antioxidant enzymes, restoring impaired mitochondria function, and regulating inflammatory cytokines, proliferation and apoptosis. These results suggest that SNE and PE could prevent DSS-induced colitis in ICR mice by protection against and/or aiding recovery from damage to the colonic epithelium, reducing ROS and maintaining normal mitochondrial function and apoptosis.
\end{abstract}

Keywords: Colitis - dextran sodium sulfate - green alga - polysaccharide - proteome analysis - Spirogyra neglecta

Asian Pac J Cancer Prev, 17 (4), 2235-2245

\section{Introduction}

One of the inflammatory bowel diseases (IBD), ulcerative colitis (UC), is a chronic disorder of the intestinal tract which is known to be linked to progression of colorectal carcinogenesis (Itzkowitz and Yio, 2004). The pathogenesis of UC remains unclear, but many studies have reported that an imbalance between proinflammatory and anti-inflammatory cytokines plays a vital role (Ardizzone and Bianchi Porro, 2005). The dextran sodium sulfate (DSS) colitis mouse model is widely used to study the etiology of UC because many pathological symptoms observed with this model are similar to those of UC in man, such as body weight loss, diarrhea, bloody feces and colonic shortening (Baumgart and Sandborn, 2007). Histologically, DSS-induced colitis is characterized by erosion, ulceration, submucosal infiltration of inflammatory cells and crypt loss (Wirtz et al., 2007). It is commonly believed that DSS causes direct toxicity to gut epithelial cells and abrogates the integrity of the mucosal barrier, allowing lumen bacteria into the lamina propria (Kitajima et al., 2000) and activating macrophages secreting pro-inflammatory cytokines such as TNF- $\alpha$ (Kaser et al., 2010).

Various kinds of drugs, include antibiotics, immunosuppressive agents and anti-inflammatory compounds, are used to cure UC, although they may have adverse side effects such as osteoporosis, neurotoxicity and gastrointestinal intolerance (Hendrickson et al., 2002). To overcome this problem, many scientists have attempted to use various natural products which could act as alternative approaches to therapy (Cho et al., 2011; Lee et al., 2013).

An extract of Spirogyra neglecta (SNE), a freshwater green alga found in the northern provinces of Thailand has been reported to exert various biological effects such as antioxidant (Thumvijit et al., 2013), antimutagenicity (Thumvijit et al., 2013), antihyperglycemia and antihyperlipidemia activities in rats with type 2 diabetes mellitus (Ontawong et al., 2013), as well as cancer chemopreventive activity with reference to development of diethylnitrosamine induced preneoplastic lesions in the

${ }^{1}$ Department of Molecular Pathology, Osaka City University Graduate School of Medicine, Asahi-machi, Abeno-ku, Osaka, Japan, ${ }^{2}$ Department of Biochemistry, Faculty of Medicine, Chiang Mai University, Chiang Mai, Thailand *For correspondence: wani@ med.osaka-cu.ac.jp 
rat liver (Thumvijit et al., 2014). Furthermore, not only different alga but also derivatives have been reported as bioactive agents (Wijesekara et al., 2011; Ngo and Kim, 2013). Importantly, the sulfated polysaccharides found in algae are known to exert antioxidant, anticoagulant, antiviral, anti-inflammatory and in vitro antitumor effects (Chattopadhyay et al., 2010; Shao et al., 2014). Furthermore, it has been reported that some herbal oligoand polysaccharides could ameliorate chemically induced colitis (Yousef et al., 2012; Zhao et al., 2014).

As it has been found that Spirogyra neglecta mainly contains sulfated polysaccharides and chlorophyll (Thumvijit et al., 2014), we hypothesized that it could have preventive effects on DSS-induced colitis. To investigate modifying effects of SNE, polysaccharide (PE) and nonpolysaccharide (CF) fractions on DSS-induced colitis in ICR mice and to elucidate mechanisms, we performed the present histopathological analysis, evaluating alteration in cellular proliferation and apoptosis, as well as identifying differentially expressed proteins and affected upstream regulators in the colon mucosa of mice after short-term administration of DSS and test agents.

\section{Materials and Methods}

\section{Chemicals}

3, 3'-diaminobenzidine tetrahydrochloride was obtained from Dojindo and dextran sodium sulfate (DSS) from ICN Biomedicals (Aurora, OH). An ApopTag ${ }^{\circledR}$ Peroxidase In Situ Apoptosis Detection Kit was purchased from Millipore and an iTRAQ Reagent 4 Plex Kit from AB Sciex. The rabbit monoclonal Ki-67 [SP6] antibody was the product of Abcam. VECTASTAIN Elite ABC was purchased from Vector Laboratories Ltd.

\section{Preparation of extracts of Spirogyra neglecta and its derivatives}

Dried S. neglecta was milled and then an extract was prepared with distilled water at $100^{\circ} \mathrm{C}$ with mechanical stirring for 2 hours. After the residue was removed by filtration the supernatant was collected, dried by lyophilizer and named the $S$. neglecta extract (SNE). Next, a polysaccharide extract, namely PE, was prepared according to Paradossi, et al (Paradossi et al., 1999) with some modification. Briefly, the SNE was dissolved in distilled water and the aqueous extract was decolorized with the solvent mixture of chloroform and methanol at the ratio 3:1. The chloroform part was collected and dried by evaporation. This extract was called the chloroform fraction $(\mathrm{CF})$. The aqueous part was precipitated with absolute ethanol $(1: 4 \mathrm{v} / \mathrm{v})$ overnight. The crude polysaccharide extract (PE) was collected by centrifugation and dried with a lyophilizer.

\section{Animals}

Male Crl: CD1 (ICR) mice were purchased from Charles River Japan (Tokyo, Japan) and housed five mice per cage. They received commercial MF diet (Oriental Yeast Co., Tokyo, Japan) and fresh tap water ad libitum. The experimental protocol was approved by the Animal Care and Use Committee of Osaka City
University Medical School. All experimental procedures were conducted under the Guidelines set by the National Institute of Health and Public Health Service Policy on the Humane Use and Care of Laboratory Animals. Mice were maintained in a room controlled at $23 \pm 1^{\circ} \mathrm{C}$ with relative humidity of $44 \pm 5 \%$ and $12 \mathrm{~h}$ light/dark cycle (8:00-20:00). All mice at 4 weeks of age were acclimatized for 1 week before starting the experiment.

\section{Induction of colitis by DSS}

Colitis was induced by the protocol previously reported by Kwon, et al with modification (Kwon et al., 2005 ) featuring drinking water containing $3 \% \mathrm{DSS}(\mathrm{w} / \mathrm{v})$ given ad libitum. The mice were randomly divided into 13 groups. In groups 3 through 10, they received 3\% DSS in their drinking water for 7 days starting one week after the commencement. In control groups (groups 1 and 2), animals were treated with Milli-Q water (vehicle control group for DSS control, SNE and PE groups) or $1 \%$ DMSO (vehicle control for CF group) by intragastric gavage (i.g.) for 2 weeks, and received tap water instead of DSS. In DSS control groups (groups 3 and 4), mice were administered Milli-Q water or $1 \%$ DMSO i.g. for 7 days and co-treated with $3 \%$ DSS for another 7 days. Mice in groups 5 through 10 orally received SNE (50 and $200 \mathrm{mg} / \mathrm{kg}$ body weight (b.w.) and PE (25 and $100 \mathrm{mg} / \mathrm{kg}$ b.w.) in Milli-Q water or $\mathrm{CF}(0.25$ and $1 \mathrm{mg} / \mathrm{kg}$ b.w.) in $1 \%$ DMSO according to the same protocol as for the DSS control groups. Animals in groups 11 through 13 were orally administered SNE (50 $\mathrm{mg} / \mathrm{kg}$ b.w.), PE (25 mg/kg b.w.) in Milli-Q water and CF $(0.25 \mathrm{mg} / \mathrm{kg}$ b.w.) in $1 \%$ DMSO for 14 days. The body weight of each mouse was recorded. The diet and water intakes were measured twice a week. At day 14, mice were sacrificed under isofluorane anesthesia and colons were immediately removed and processed for histological assessment and immunohistochemical examination or frozen for molecular analysis. The weights of internal organs including liver, kidneys and spleen were measured.

\section{Histopathological examination}

Portions of colon were fixed in $10 \%$ neutral formalin solution and embedded in paraffin for sectioning at $3 \mu \mathrm{m}$ and staining with hematoxylin and eosin. Histologically, the damage to colon mucosa was assessed as described previously (Cooper et al., 1993). In brief, the pathophysiology of the colon was characterized by the presence of edema, infiltration of inflammatory cells into submucosa and crypt loss. Scores were given for grades as follows; a) edema ( 0 : none; 1 : mild; 2 : moderate and 3 : severe); b) inflammatory cell infiltration into submucosa (0: none; 1 : mild; 2 : moderate and 3 : severe); c) crypt loss ( 0 : none; 1 : $1 / 3$ loss; $2: 2 / 3$ loss; 3 : entire loss). The histological score for the pathophysiology of the colon was calculated as the sum of these three parameters, giving a maximum score of 9 .

\section{Immunohistochemical assessment of Ki-67 and apoptosis}

Changes in cell proliferation and cell cycle arrest were analyzed by Ki-67 immunohistochemistry. From paraffin embedded samples, $3 \mu \mathrm{m}$ sections were cut, deparaffinized and rehydrated. After antigen retrieval, the endogenous 
peroxidase was blocked by incubation in $3 \%$ hydrogen peroxide solution. Then, samples were treated with normal serum for $15 \mathrm{~min}$. Incubation of tissue sections with anti-Ki-67 antibodies (SP6, Abcam, USA, dilution 1:500) was at $4^{\circ} \mathrm{C}$ overnight. After primary antibody incubation and washing, the secondary antibody was added onto the tissue sections and incubated for $30 \mathrm{~min}$ at room temperature. The VECTASTAIN Elite ABC solution was incubated with the specimens for $30 \mathrm{~min}$ at room temperature. Antigen visualization was accomplished with 3,3'-diaminobenzidine tetrahydrochloride (DAB). At least 3000 mucosa cell nuclei in each colon part were counted and labeling indices were calculated as the percentages of cells positive for Ki-67.

Apoptosis was investigated using a terminal deoxynucleotidyl transferase-mediated dUTP nick-end labeling (TUNEL) staining kit (Riezzo et al., 2014). Tissue sections were pre-treated with proteinase $\mathrm{K}$ and incubated with the working strength TdT enzyme, followed by working strength stop/wash buffer and then anti-digoxigenin peroxidase conjugate. Antigens were visualized with DAB peroxidation. Labeling indices were calculated from 12 fields per section of each colon (proximal middle and distal) part and expressed as percentages of positive cells for TUNEL in all examined colonic mucosa cells.

\section{LC-MS/MS analysis}

Pooled samples of mice colonic mucosa were prepared in 9M Urea/2\% CHAPS and T-PER lysis buffers with protease inhibitor. The samples were homogenized and then centrifuged at $10,000 \mathrm{rpm}$ for $10 \mathrm{~min}$ at $4^{\circ} \mathrm{C}$. For $9 \mathrm{M}$ Urea/2\% CHAPS tissue lysates acetone precipitation was performed and the protein concentration in each sample was determined using BCA Protein Assay Kit (Pierce, IL, USA). Each pooled sample contained $40 \mu \mathrm{g}$ protein. Protein Reduction, Alkylation and iTRAQ labeling were performed using an iTRAQ Reagent 4 Plex Kit according to standard procedures (Gluckmann et al., 2007). Pooled samples were labeled as described below: iTRAQ isobaric reagents 114, normal colon mucosa of mice in the vehicle control group; 115, colon mucosa of mice in the DSS control group; 116, colon mucosa of mice in the DSS and SNE-treated group; 117, colon mucosa of mice in the DSS and PE-treated group. The iTRAQ labeled samples were combined and applied to ICAT cation exchange column and eluted as six fractions with 10, 50, 70, 100, 200 and $350 \mathrm{mM} \mathrm{KCl}$ followed by evaporation in a vacuum centrifuge. The peptides in each fraction were resuspended in $2 \%$ acetonitrile and desalted with a SepPak C18 Plus light cartridge. After desalting, the peptides in each fraction were evaporated and dissolved in $0.1 \%$ $(\mathrm{v} / \mathrm{v})$ formic acid. Proteome analysis was performed with a DiNa-AI nano system coupled to a QSTAR Elite Hybrid mass spectrometer through a Nano Spray ion source. MS/ MS data were searched against the Swiss Protein database (MOUSE) using ProteinPilot ${ }^{\mathrm{TM}}$ software (version 2.0, AB Sciex, Concord, ON, Canada) with trypsin set as the digestion enzyme and methyl methanethiosulfonate as the cysteine modification. The search results were further processed by ProteinPilot ${ }^{\mathrm{TM}}$ software using the Paragon
Algorithm for redundant hits removal and comparative quantitation, resulting in a minimal set of justifiable identified proteins. Each sample was measured 3 times and all reported data were used at the $95 \%$ confidence cut-off limit created by the ProteinPilot ${ }^{\mathrm{TM}}$ software. The same program was used to remove the bias for proteins expressed at very low levels. Protein ratios with a p-value less than 0.05 were considered reliable. Previously standard deviations of the protein ratio, which stem from technical variation, were reported to be less than 0.3 in $90 \%$ of iTRAQ experimental runs (Song et al., 2008). In this experiment, expression changes greater than 1.2-fold or less than 0.83 -fold in normalized expression levels were considered to be outside the range of technical variability.

\section{Ingenuity Pathway Analysis (IPA)}

To assign biological significance to differentially labeled proteins, to identify function and networks of interacting proteins, functional groups and pathways, and to predict activated up-stream regulators by DSS, DSS and SNE or DSS and PE treatment groups, the Ingenuity program (Ingenuity Systems, Mountain View, CA) was utilized. Transcriptional regulation was measured by the $\mathrm{z}$-score. The basis for $\mathrm{z}$-score predictions are relationships in the molecular pathways (networks) which represent experimentally observed protein expression or transcription events. A z-score of above 2 or lower than -2 was considered significant.

\section{Statistical analysis}

The results are presented as mean value \pm standard deviation (SD). Data were analyzed using the Statlight program (Yukms Co., Ltd, Tokyo, Japan), and the significance of differences for each parameter (excluding general conditions) was analyzed and evaluated at the level of a) $p<0.05$ vs vehicle control group or b) $p<0.05$ vs DSS control group. Statistical comparisons of numerical data between the DSS control group and DSS and SNE or DSS and PE treatment groups were conducted using the Bartlett's test. If homogeneous, the data were analyzed with the Dunnett's multiple comparison test (two-sided), and if not, with the Steel's test (two- sided). Statistical comparisons between Milli-Q and tap water control and DSS control groups for numerical data were assessed using the F test. If homogeneous, the data were analyzed with the Student's t-test (two-sided), and if not, with the Welch test.

\section{Results}

\section{Symptomatic change}

The trends for body weight decrease, which is one of the symptomatic parameters of colitis, were observed in all groups administered DSS at days 5, 6 and 7 after starting application (data not shown). No significant differences of final body weights were found in groups administered DSS and pre-treated with SNE, PE or CF, as compared to DSS controls (Table 1). Furthermore, no significant body weight changes were found in mice of vehicle control, SNE, PE and CF alone groups.

DSS treatment caused an increase in relative liver 
Sirinya Taya et al

weight when compared to control group, but without significance. Interestingly, a significant reduction and a tendency for decrease of relative liver weights were observed in PE and SNE-treated groups, respectively, at both low and high doses as compared to the DSS control group (Table 1). No significant changes in relative liver, kidney and spleen weights were detected in mice administered vehicles, SNE, PE and CF alone.

\section{Histopathological changes in the colonic mucosa}

The histological scores of pathological changes in colonic mucosa of mice are summarized in Table 2. A normal colonic architecture was observed in mice of vehicle control groups (Figure 1A and B). The colon of DSS-treated mice presented submucosal edema, infiltration of inflammatory cells to submucosa, loss of crypts, epithelial erosion and ulceration (Figure 1C and D).
Interestingly, treatment with SNE, PE and to a lesser extent CF prior to and in combination with DSS ameliorated those pathological changes in the colon (Figure $1 \mathrm{E}$ and $\mathrm{F}$, $1 \mathrm{G}$ and $\mathrm{H}$ and $1 \mathrm{I}$ and $\mathrm{J}$ ). Crypt structures were preserved and the numbers of infiltrated inflammatory cells were decreased, resulting in the low histological scores for colons of SNE, PE and CF-treated mice (Table 2).

Induction of cell cycle arrest and apoptosis by DSS and its prevention by SNE and $P E$

The percentage of $\mathrm{Ki}-67$ positive cells tended to decrease in DSS-treated mice colons, indicating induction of cell cycle arrest due to significant damage to colon epithelial cells. However, administration of SNE and PE caused recovery of Ki-67 positive cell number up to the level observed in the vehicle control group (Table 2). No significant differences in Ki-67 positive cell indices were

Table 1. Final Body and Relative Liver, Kidneys and Spleen Weights of Mice Treated with DSS or Vehicles and Administered SNE, PE and CF Extracts at Low and High Doses

\begin{tabular}{|c|c|c|c|c|c|}
\hline \multirow{2}{*}{ Treatment } & \multirow{2}{*}{ No. of mice } & \multirow{2}{*}{$\begin{array}{l}\text { Final body } \\
\text { weight (g) }\end{array}$} & \multicolumn{3}{|c|}{ Relative organ weight (\%) } \\
\hline & & & Liver & Kidneys & Spleen \\
\hline Tap water + Milli-Q & 5 & $32.9 \pm 1.4$ & $3.56 \pm 0.24$ & $1.41 \pm 0.11$ & $0.31 \pm 0.05$ \\
\hline Tap water + $1 \%$ DMSO & 5 & $32.6 \pm 1.7$ & $3.70 \pm 0.26$ & $1.25 \pm 0.11$ & $0.30 \pm 0.03$ \\
\hline 3\% DSS + Milli-Q & 5 & $31.9 \pm 1.3$ & $4.58 \pm 0.48$ & $1.33 \pm 0.13$ & $0.73 \pm 0.37$ \\
\hline $3 \% \mathrm{DSS}+1 \% \mathrm{DMSO}$ & 5 & $31.4 \pm 1.4$ & $3.92 \pm 0.43$ & $1.34 \pm 0.11$ & $0.43 \pm 0.11$ \\
\hline $3 \% \mathrm{DSS}+\mathrm{SNE} 50 \mathrm{mg} / \mathrm{kg}$ b.w. & 5 & $30.1 \pm 2.8$ & $4.14 \pm 0.30$ & $1.28 \pm 0.16$ & $0.76 \pm 0.20$ \\
\hline $3 \% \mathrm{DSS}+\mathrm{SNE} 200 \mathrm{mg} / \mathrm{kg} \mathrm{b} . \mathrm{w}$. & 4 & $31.6 \pm 1.2$ & $4.06 \pm 0.54$ & $1.37 \pm 0.12$ & $0.64 \pm 0.33$ \\
\hline $3 \% \mathrm{DSS}+\mathrm{PE} 25 \mathrm{mg} / \mathrm{kg}$ b.w. & 5 & $30.5 \pm 1.5$ & $3.90 \pm 0.28^{b}$ & $1.50 \pm 0.16$ & $0.63 \pm 0.25$ \\
\hline 3\% DSS + PE 100 mg/kg b.w. & 5 & $31.8 \pm 0.6$ & $3.89 \pm 0.23^{\mathrm{b}}$ & $1.43 \pm 0.15$ & $0.59 \pm 0.11$ \\
\hline $3 \% \mathrm{DSS}+\mathrm{CF} 0.25 \mathrm{mg} / \mathrm{kg}$ b.w. in $1 \%$ DMSO & 5 & $32.3 \pm 1.4$ & $3.85 \pm 0.29$ & $1.37 \pm 0.15$ & $0.65 \pm 0.23$ \\
\hline $3 \% \mathrm{DSS}+\mathrm{CF} 1 \mathrm{mg} / \mathrm{kg}$ b.w. in $1 \% \mathrm{DMSO}$ & 5 & $31.1 \pm 1.4$ & $3.77 \pm 0.48$ & $1.36 \pm 0.07$ & $0.42 \pm 0.17$ \\
\hline Tap water + SNE 50 mg/kg b.w. & 4 & $32.4 \pm 0.9$ & $3.55 \pm 0.17$ & $1.39 \pm 0.09$ & $0.28 \pm 0.05$ \\
\hline Tap water + PE 25 mg/kg b.w. & 5 & $31.0 \pm 2.1$ & $3.72 \pm 0.44$ & $1.39 \pm 0.05$ & $0.33 \pm 0.20$ \\
\hline Tap water + CF $0.25 \mathrm{mg} / \mathrm{kg}$ b.w. in $1 \%$ DMSO & 4 & $32.4 \pm 0.8$ & $3.54 \pm 0.20$ & $1.31 \pm 0.06$ & $0.26 \pm 0.04$ \\
\hline
\end{tabular}

Data are mean \pm SD. ${ }^{\mathrm{b}} \mathrm{p}<0.05$ v.s. the $\mathrm{DSS}+$ Milli-Q control group.

Table 2. Histological Scores, and Ki-67 and TUNEL Indices in the Colons of Mice Treated with DSS or Vehicles and Administered SNE, PE and CF Extracts at low and High Doses

\begin{tabular}{lccc}
\hline \multicolumn{1}{c}{ Treatment } & Histological score & $\begin{array}{c}\text { Ki-67 positive cell } \\
\text { index }(\%)\end{array}$ & $\begin{array}{c}\text { TUNEL positive cell } \\
\text { index }(\%)\end{array}$ \\
\hline Tap water + Milli-Q & $0.0 \pm 0.0$ & $33.4 \pm 3.7$ & $0.5 \pm 0.1$ \\
Tap water + 1\% DMSO & $0.0 \pm 0.0$ & $28.9 \pm 2.9$ & $0.4 \pm 0.1$ \\
3\% DSS + Milli-Q & $3.9 \pm 2.1^{\mathrm{a}}$ & $19.3 \pm 4.3$ & $2.2 \pm 0.7^{\mathrm{a}}$ \\
3\% DSS + 1\% DMSO & $4.2 \pm 1.2^{\mathrm{a}}$ & $23.3 \pm 6.1$ & $2.0 \pm 0.3^{\mathrm{a}}$ \\
3\% DSS + SNE 50 mg/kg b.w. & $3.5 \pm 0.7$ & $41.2 \pm 5.9^{\mathrm{b}}$ & $1.4 \pm 0.2^{\mathrm{b}}$ \\
3\% DSS + SNE 200 mg/kg b.w. & $3.0 \pm 1.7$ & $33.2 \pm 4.8^{\mathrm{b}}$ & $1.1 \pm 0.5^{\mathrm{b}}$ \\
3\% DSS + PE 25 mg/kg b.w. & $2.8 \pm 0.9$ & $35.4 \pm 8.1^{\mathrm{b}}$ & $0.9 \pm 0.3^{\mathrm{b}}$ \\
3\% DSS + PE 100 mg/kg b.w. & $3.4 \pm 0.8$ & $36.5 \pm 9.0^{\mathrm{b}}$ & $1.3 \pm 0.5^{\mathrm{b}}$ \\
3\% DSS + CF 0.25 mg/kg b.w. in 1\% DMSO & $3.4 \pm 1.0$ & $29.5 \pm 4.8$ & $1.2 \pm 0.3^{\mathrm{b}}$ \\
3\% DSS + CF 1 mg/kg b.w. in 1\% DMSO & $3.4 \pm 1.0$ & $23.9 \pm 6.0$ & $1.3 \pm 0.3^{\mathrm{b}}$ \\
Tap water + SNE 50 mg/kg b.w. & $0.0 \pm 0.0$ & $26.8 \pm 0.7^{\mathrm{a}}$ & $0.6 \pm 0.0$ \\
Tap water + PE 25 mg/kg b.w. & $0.0 \pm 0.0$ & $28.7 \pm 2.1^{\mathrm{a}}$ & $0.7 \pm 0.1$ \\
Tap water + CF 0.25 mg/kg b.w. in 1\% DMSO & $0.0 \pm 0.0$ & $24.9 \pm 5.3$ & $0.7 \pm 0.2$ \\
\hline
\end{tabular}

Data are mean $\pm \mathrm{SD} ;{ }^{\mathrm{a}} \mathrm{p}<0.05$ v.s. Tap water + Milli-Q or Tap water $+1 \%$ DMSO control group; ${ }^{\mathrm{b}} \mathrm{p}<0.05$ versus the DSS+ Milli-Q or DSS $+1 \%$ DMSO control group. 
found in CF and DSS-administered mice as compared to the concomitant DSS control group.

The number of apoptotic cells was low in the vehicle control groups but significantly increased in DSSadministered animals. Similarly to observed alterations of Ki-67, SNE, PE and CF application prior to DSS application led to reduction of apoptosis positive cell indices becoming close to the level observed in the vehicle control group (Table 2).

\section{Alteration of protein expression in mouse colons and IPA} analysis

In this study, we investigated alterations of protein expression in the colon mucosa which might explain the mechanisms of DSS-induced colitis in mice and further
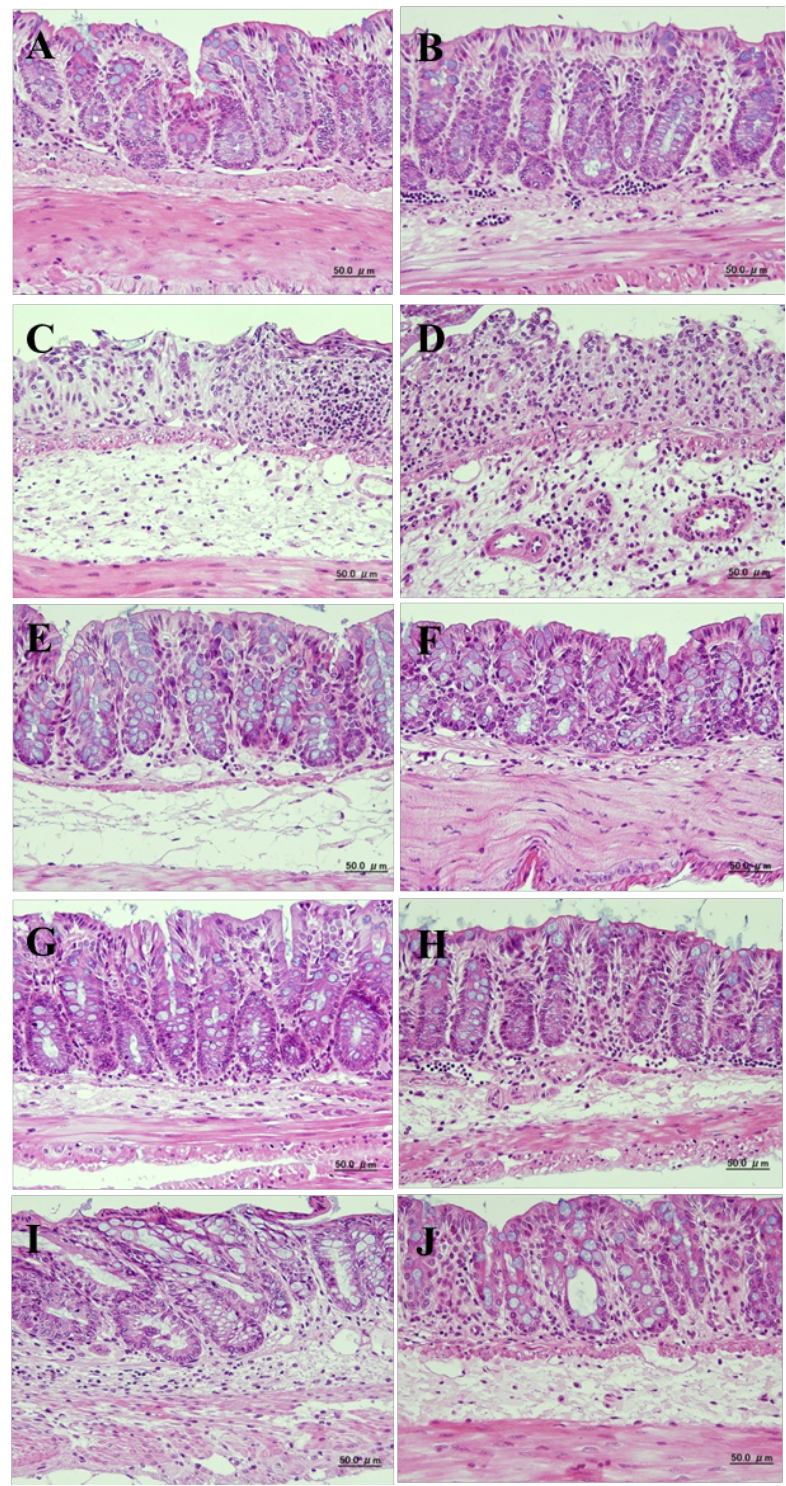

Figure 1. Histological Changes in Colonic Mucosa in Mice with DSS-induced Colitis and Modifying Effects of SNE, PE and CF. (A-J) Representative microphotographs of HE stained mice colons from Milli-Q control (A), DMSO control (B), DSS control (C), DSS-DMSO control (D), DSS-SNE (50 mg/kg b.w.) (E), DSS-SNE (200 mg/kg b.w.) (F), DSS-PE ( $25 \mathrm{mg} / \mathrm{kg}$ b.w.) (G), DSS-PE (100 mg/kg b.w.) (H), DSS-CF $(0.25 \mathrm{mg} / \mathrm{kg}$ b.w.) (I), and DSS-CF (1 mg/kg b.w.) (J) groups explain the preventive effects of SNE and PE. The results of QSTAR Elite LC-MS/MS and IPA are summarized in Table 3. A total of 49 differentially expressed proteins were identified in 3 sample pairs for comparison: a) DSS control and vehicle control; b) SNE $\rightarrow$ DSS and vehicle control: and c) PE $\rightarrow$ DSS-treated and vehicle control colon mucosa. It was observed that differentially expressed proteins in mice treated with DSS were involved in xenobiotic metabolism, oxidation-reduction process, glutathione and lipid metabolism, mitochondrial function, calcium metabolism, transcription, protein synthesis, protein peroxisome proliferation, cytoskeleton organization, cell proliferation and apoptosis processes.

According to the IPA upstream regulator analysis, after 7 days on DSS, in colons of mice proteins regulated by c-Myc, NMYC, TNF- $\alpha$ and transcriptional factor X-boxbinding protein 1 (XBP1) associated with cell proliferation and angiogenesis were up-regulated but those promoting apoptosis, such as a tumor suppressor gene cellular tumor antigen p53 (p53), were inhibited, which could be the adaptive response to the severe cellular damage, cell cycle arrest and cell death induced by DSS (Table 4).

Interestingly, IPA indicated that pretreatment of mice with SNE and PE protected against activation of up-stream regulators TNF- $\alpha$, nuclear receptor subfamily 3 , group C, member 1 (glucocorticoid receptor) (NR3C1), heat shock transcription factor 2 (HSF2), XBP1 and pancreatic and duodenal homeobox 1 (PDX1), and suppressed activity of several genes and cell kinases involved in cell proliferation. Those included SWI/SNF related, matrix associated, actin dependent regulator of chromatin, subfamily a, member 4 (SMARCA4), cAMP responsive element binding protein 1 (CREB1), erb-b2 receptor tyrosine kinase 4 (ERBB4), prohibitin 2 (PHB2), insulin-like growth factor 1 receptor (IGF1R), presenilin 2 (PSEN2), Raf kinase 1 (RAF1), mitogen-activated protein kinases (MAPK) p38 MAPK, ERK1/2 and MAP2K1, peroxisome proliferator-activated receptors alpha (PPARA), gamma, coactivator 1 alpha (PPARGC1A) and beta (PPARGC1B) (Tables 3 and 4). Furthermore, DSS suppressed the expression of keratins 8 (KRT8) and 18 (KRT18) in the colons of mice. We also found that SNE and PE ameliorated down-regulation of proteins involved in cytoskeleton organization including tropomyosin 1, alpha (Tpm 1) and tropomyosin 2, beta (Tpm 2) and inhibited expression of cytokeratin 19 (CK19) (Table 3).

Importantly, it was observed that DSS treatment induced activation of nuclear receptor subfamily 1 , group I, member 2 (PXR) which could result in generation of reactive oxygen species (ROS) in the colon mucosa (Table 4). Again, SNE and PE blocked this activation, in coordination with preventive effects on cell proliferation. Furthermore, PE suppressed up-regulation of proteins such as cytochrome $\mathrm{P} 450$, family 2 , subfamily $\mathrm{C}$, polypeptide 9 (CYP2C9) involved in generation of oxidative stress (Table 3). In addition, in proteome analysis, downregulation of cytochrome $\mathrm{c}$ oxidase subunit $\mathrm{Va}$ (COX5A) and glutathione reductase (GSR) enzymes participating in maintenance of normal mitochondrial function and antioxidant response was observed in DSS-induced colitis as compared to vehicle controls (Table 3). However, PE 
Table 3. Differentially Expressed Proteins in the Colon Mucosa of Mice Treated with DSS Alone or in Combination with SNE and PE, Identified by QSTAR Elite LC-MS/MS and IPA

\begin{tabular}{|c|c|c|c|c|c|c|c|c|c|c|c|}
\hline \multirow{2}{*}{$\begin{array}{l}\text { Protein Name } \\
\quad(\text { Symbol })\end{array}$} & \multirow{2}{*}{ GI Number } & \multicolumn{2}{|c|}{ DSS vs vehicle } & \multicolumn{2}{|c|}{$\begin{array}{l}\text { DSS SNE vs } \\
\text { vehicle }\end{array}$} & \multicolumn{2}{|c|}{$\begin{array}{l}\text { DSS PE vs } \\
\text { vehicle }\end{array}$} & \multirow{2}{*}{ Location } & \multirow{2}{*}{ Type } & \multirow{2}{*}{ Function } & \multirow{2}{*}{ Up-stream regulator } \\
\hline & & $\mathrm{FC}$ & p-value & $\mathrm{FC}$ & $\begin{array}{c}\mathrm{p}- \\
\text { value }\end{array}$ & $\mathrm{FC}$ & p-value & & & & \\
\hline $\begin{array}{c}\text { carboxylesterase } \\
2 \mathrm{~A}(\mathrm{Ces} 2 \mathrm{a})\end{array}$ & 19527178 & $\mathrm{NC}$ & & $\mathrm{NC}$ & & -1.43 & 0.022 & $\mathrm{C}$ & $\mathrm{E}$ & M & NR1/2, NR1/3 \\
\hline $\begin{array}{l}\text { carboxylesterase } \\
\text { 2C (Ces } 2 \mathrm{c})\end{array}$ & 21704206 & -1.17 & 0.0008 & -1.27 & 0 & -1.62 & 0 & $\mathrm{C}$ & $\mathrm{E}$ & M & NR1/2, NR1/3 \\
\hline $\begin{array}{c}\text { aldehyde } \\
\text { dehydrogenase } 1 \\
\text { family, member } \\
\text { A1 (ALDH1A1) }\end{array}$ & 85861182 & -1.32 & 0 & $\mathrm{NC}$ & & -1.73 & 0 & $\mathrm{C}$ & $\mathrm{E}$ & M & $\mathrm{N} 1 / 2, \mathrm{~N} 1 / 3$ \\
\hline $\begin{array}{l}\text { adenosylho- } \\
\text { mocysteinase } \\
\text { (AHCY) }\end{array}$ & 262263372 & -1.09 & 0.047 & -1.19 & 0.0021 & -1.22 & 0.034 & $\mathrm{C}$ & $\mathrm{E}$ & M & $\mathrm{N} 1 / 2$ \\
\hline $\begin{array}{c}\text { cytochrome } \\
\text { P450, fam. 2, } \\
\text { subfam. C, } \\
\text { polypep. } 9 \\
\text { (CYP2C9) }\end{array}$ & 268607516 & 1.2 & 0.031 & 1.09 & 0.0001 & -1.2 & 0.022 & $\mathrm{C}$ & $\mathrm{E}$ & $\mathrm{XM}, \mathrm{OR}$ & $\begin{array}{c}\mathrm{N} 1 / 2, \\
\mathrm{~N} 1 / 3, \mathrm{PPARGC} 1 \mathrm{~A}\end{array}$ \\
\hline $\begin{array}{l}\text { cytochrome } \\
\text { P450, fam. 2, } \\
\text { subfam. C, } \\
\text { polypep. } 18 \\
\text { (CYP2C18) }\end{array}$ & 13386282 & -1.1 & 0.0005 & $\mathrm{NC}$ & & -2.12 & 0 & $\mathrm{C}$ & $\mathrm{E}$ & $\mathrm{XM}, \mathrm{OR}$ & \\
\hline $\begin{array}{c}\text { glutathione } \\
\text { S-transferase, } \\
\text { alpha } 4 \text { (Gsta4) }\end{array}$ & 160298217 & 1.15 & 0.048 & $\mathrm{NC}$ & & -1.24 & 0.0013 & $\mathrm{O}$ & $\mathrm{E}$ & GM & N1/2, PPARA \\
\hline $\begin{array}{l}\text { glutathione S- } \\
\text { transferase mu } 1 \\
\text { (GSTM1) }\end{array}$ & 6680121 & -1.36 & 0.0009 & -1.67 & 0.0003 & -1.63 & 0 & $\mathrm{C}$ & $\mathrm{E}$ & GM & N1/2, N1/3, TP53 \\
\hline $\begin{array}{l}\text { glutathione S- } \\
\text { transferase mu } 5 \\
\text { (GSTM5) }\end{array}$ & 6754084 & -1.95 & 0 & -2.1 & 0 & -2.4 & 0 & $\mathrm{C}$ & $\mathrm{E}$ & GM & N1/2, SRF, TP53 \\
\hline $\begin{array}{l}\text { sulfotransferase } \\
\text { family } 1 \mathrm{~A}, \\
\text { phenol-pref., } \\
\text { member } 1 \\
\text { (Sult1a1) }\end{array}$ & 19526822 & $\mathrm{NC}$ & & -1.36 & 0.0007 & -2.24 & 0.002 & $\mathrm{C}$ & $\mathrm{E}$ & XM & $\mathrm{N} 1 / 3$ \\
\hline $\begin{array}{l}\text { 3'-phospho- } \\
\text { adenosine }\end{array}$ & & & & & & & & & & & \\
\hline $\begin{array}{l}\text { 5'-phosphosul- } \\
\text { fate synthase } 2 \\
\text { (PAPSS2) }\end{array}$ & 61098088 & 1.14 & 0.0013 & 1.22 & 0.0012 & $\mathrm{NC}$ & & $\mathrm{C}$ & $\mathrm{E}$ & SM & $\mathrm{N} 1 / 3$ \\
\hline $\begin{array}{l}\text { calnexin } \\
\text { (CANX) }\end{array}$ & 6671664 & 1.37 & 0 & 1.42 & 0.0007 & 1.38 & 0.0004 & $\mathrm{C}$ & $\mathrm{O}$ & $\mathrm{CaM}$ & c-MYC \\
\hline $\begin{array}{c}\text { cytochrome c } \\
\text { oxidase subunit } \\
\text { Va (COX5A) }\end{array}$ & 112181182 & -1.54 & 0 & -1.32 & 0 & -1.34 & 0.0002 & $\mathrm{C}$ & $\mathrm{E}$ & MitF & \\
\hline $\begin{array}{l}\text { glutathione re- } \\
\text { ductase (GSR) }\end{array}$ & 160298213 & -1.85 & 0 & -1.62 & 0 & $\mathrm{NC}$ & & $\mathrm{C}$ & $\mathrm{E}$ & MitF & \\
\hline $\begin{array}{l}\text { prohibitin } 2 \\
\text { (PHB2) }\end{array}$ & 126723336 & $\mathrm{NC}$ & & -1.18 & 0.022 & -1.45 & 0.02 & $\mathrm{C}$ & $\mathrm{TR}$ & TRA & c-MYC \\
\hline $\begin{array}{l}\text { nucleophosmin } \\
\text { (NPM1) }\end{array}$ & 6679108 & 1.31 & 0.001 & 2.09 & 0 & 1.95 & 0 & $\mathrm{~N}$ & $\mathrm{TR}$ & TRA & $\begin{array}{c}\mathrm{c}-\mathrm{MYC}, \mathrm{MYCN}, \\
\mathrm{SRF}\end{array}$ \\
\hline nucleolin (NCL) & 84875537 & 1.22 & 0 & 1.37 & 0 & 1.5 & 0 & $\mathrm{~N}$ & $\mathrm{O}$ & $\mathrm{CP}$ & $\begin{array}{c}\text { c-MYC, } \\
\text { MYCN,ERBB4 }\end{array}$ \\
\hline $\begin{array}{c}\text { ribosomal } \\
\text { protein L10a } \\
(\mathrm{RPL} 10 \mathrm{~A})\end{array}$ & 255003735 & 2.44 & 0 & 2.84 & 0 & 2.94 & 0 & $\mathrm{~N}$ & SCR & PS & c-MYC, MYCN \\
\hline $\begin{array}{l}\text { ribosomal } \\
\text { protein L13 } \\
(\text { RPL13) }\end{array}$ & 33186863 & 2.19 & 0.0022 & 2.58 & 0.0043 & 2.45 & 0.0076 & $\mathrm{~N}$ & SCR & PS & c-MYC, MYCN \\
\hline $\begin{array}{l}\text { ribosomal } \\
\text { protein L14 } \\
\text { (RPL14) }\end{array}$ & 13385472 & 1.95 & 0 & 2.79 & 0 & 2.91 & 0 & $\mathrm{C}$ & SCR & PS & c-MYC, MYCN \\
\hline
\end{tabular}



in Combination with SNE and PE, Identified by QSTAR Elite LC-MS/MS and IPA

\begin{tabular}{|c|c|c|c|c|c|c|c|c|c|c|c|}
\hline $\begin{array}{l}\text { ribosomal } \\
\text { protein L24 } \\
\text { (RPL24) }\end{array}$ & 18250296 & 1.84 & 0.0007 & 2.42 & 0.0001 & 2.58 & 0.0001 & $\mathrm{C}$ & SCR & PS, AP & c-MYC, MYCN \\
\hline $\begin{array}{l}\text { ribosomal } \\
\text { protein L28 } \\
\text { (RPL28) }\end{array}$ & 6677779 & 2.41 & 0.0028 & 3.09 & 0.0024 & 3.2 & 0.0012 & $\mathrm{C}$ & SCR & PS & c-MYC, MYCN \\
\hline $\begin{array}{l}\text { ribosomal pro- } \\
\text { tein L32 (Rpl32) }\end{array}$ & 25742730 & 2.2 & 0.0018 & 2.2 & 0.0012 & 2.55 & 0.0016 & $\mathrm{C}$ & SCR & PS & c-MYC, MYCN \\
\hline $\begin{array}{l}\text { ribosomal pro- } \\
\text { tein L4 (RPL4) }\end{array}$ & 30794450 & 2.13 & 0 & 2.29 & 0 & 2.24 & 0 & $\mathrm{C}$ & $\mathrm{E}$ & PS & c-MYC, MYCN \\
\hline $\begin{array}{l}\text { ribosomal pro- } \\
\text { tein L6 (RPL6) }\end{array}$ & 84662736 & 2.46 & 0 & 2.67 & 0 & 2.56 & 0 & $\mathrm{~N}$ & SCR & PS & c-MYC, MYCN \\
\hline $\begin{array}{l}\text { ribosomal pro- } \\
\text { tein L8 (RPL8) }\end{array}$ & 6755358 & 2 & 0.003 & 2.11 & 0.0039 & 2.07 & 0.0076 & $\mathrm{O}$ & SCR & PS, PM & c-MYC, MYCN \\
\hline $\begin{array}{l}\text { ribosomal } \\
\text { protein S24 } \\
\text { (RPS24) }\end{array}$ & 46519158 & 2.21 & 0.0005 & 2.35 & 0.0004 & 2.41 & 0.0004 & $\mathrm{C}$ & SCR & PS & c-MYC, MYCN \\
\hline $\begin{array}{l}\text { ribosomal } \\
\text { protein S3A1 } \\
(\mathrm{Rps} 3 \mathrm{a} 1)\end{array}$ & 254553321 & 2.07 & 0 & 2.3 & 0 & 2.6 & 0 & $\mathrm{C}$ & SCR & PS & c-MYC, MYCN \\
\hline $\begin{array}{l}\text { ribosomal } \\
\text { protein S6, } \\
\text { pseudogene } 4 \\
\text { (Rps6-ps4) }\end{array}$ & 94367038 & 3.09 & 0.0006 & 3.82 & 0.0044 & 4.23 & 0.0027 & $\mathrm{O}$ & SCR & PS & c-MYC, MYCN \\
\hline $\begin{array}{l}\text { S100 calcium } \\
\text { binding protein } \\
\text { A10 }(\mathrm{S} 100 \mathrm{~A} 10)\end{array}$ & 6677833 & 1.45 & 0.013 & 1.78 & 0.0009 & 1.37 & 0.0013 & $\mathrm{C}$ & $\mathrm{O}$ & $\mathrm{CaM}$ & c-MYC, MYCN \\
\hline $\begin{array}{l}\text { eukaryotic trans- } \\
\text { lation elongation } \\
\text { factor } 1 \text { gamma } \\
\text { (EEF1G) }\end{array}$ & 110625979 & 1.47 & 0 & 1.6 & 0 & 1.57 & 0 & $\mathrm{C}$ & TR & TRA & MYCN \\
\hline $\begin{array}{c}\text { peroxiredoxin } 6 \\
\text { (PRDX6) }\end{array}$ & 6671549 & -1.42 & 0 & -2.11 & 0 & -1.93 & 0 & $\mathrm{C}$ & $\mathrm{E}$ & $\mathrm{AP}$ & TP53 \\
\hline $\begin{array}{c}\text { 4-aminobutyrate } \\
\text { aminotransferase } \\
\text { (ABAT) }\end{array}$ & 37202121 & -1.64 & 0.0011 & -1.86 & 0.0001 & -2.24 & 0.0003 & $\mathrm{C}$ & $\mathrm{E}$ & $\mathrm{AP}$ & TP53 \\
\hline $\begin{array}{l}\text { calreticulin } \\
\text { (CALR) }\end{array}$ & 6680836 & 1.16 & 0 & 1.41 & 0.0003 & 1.51 & 0.0003 & $\mathrm{C}$ & TR & TRA & TNF, XBP1 \\
\hline $\begin{array}{c}\text { actinin, alpha } 1 \\
\text { (ACTN1) }\end{array}$ & 61097906 & -1.13 & 0.011 & -1.28 & 0.0006 & -1.41 & 0 & $\mathrm{C}$ & TR & TRA & TP53, c-MYC \\
\hline $\begin{array}{l}\text { actin, alpha } 2, \\
\text { smooth muscle, } \\
\text { aorta (ACTA2) }\end{array}$ & 6671507 & -1.48 & 0.0001 & -1.56 & 0.0004 & -2.67 & 0 & $\mathrm{C}$ & $\mathrm{CS}$ & $\mathrm{CO}$ & TP53, SP1, ERBB4 \\
\hline $\begin{array}{l}\text { transgelin } \\
\text { (TAGLN) }\end{array}$ & 6755714 & -1.98 & 0 & -2.13 & 0 & -2.59 & 0 & $\mathrm{C}$ & $\mathrm{CS}$ & $\mathrm{CO}$ & c-MYC, MYCN \\
\hline $\begin{array}{c}\text { transgelin } 2 \\
(\text { TAGLN2) }\end{array}$ & 30519911 & -1.19 & 0.0098 & -1.19 & 0.0009 & -1.44 & 0 & $\mathrm{C}$ & $\mathrm{CS}$ & $\mathrm{CO}$ & $\begin{array}{c}\text { c-MYC, } \\
\text { MYCN,TP53 }\end{array}$ \\
\hline $\begin{array}{l}\text { tropomyosin } 1, \\
\text { alpha }(\mathrm{Tpm} 1)\end{array}$ & 31560030 & -2.84 & 0 & -2.18 & 0 & -2.23 & 0 & $\mathrm{PM}$ & $\mathrm{CS}$ & $\mathrm{CO}$ & c-MYC, SRF \\
\hline $\begin{array}{l}\text { tropomyosin } 2, \\
\text { beta }(\mathrm{Tpm} 2)\end{array}$ & 482677666 & -3.02 & 0 & -2.65 & 0 & -2.15 & 0 & $\mathrm{C}$ & $\mathrm{CS}$ & $\mathrm{CO}$ & c-MYC,RAF, SRF \\
\hline vimentin (VIM) & 31982755 & -1.22 & 0 & -1.61 & 0 & -1.23 & 0.0002 & $\mathrm{C}$ & $\mathrm{CS}$ & $\mathrm{CO}$ & $\begin{array}{c}\text { c-MYC, MYCN, } \\
\text { TP53 }\end{array}$ \\
\hline $\begin{array}{c}\text { keratin 8, type II } \\
\text { (KRT8) }\end{array}$ & 114145561 & -1.73 & 0 & -1.23 & 0 & -1.64 & 0 & $\mathrm{C}$ & $\mathrm{CS}$ & $\mathrm{CO}, \mathrm{AP}$ & TP53, PPARA \\
\hline $\begin{array}{l}\text { keratin } 18, \text { type I } \\
(\text { KRT18) }\end{array}$ & 254540068 & -2.06 & 0.0001 & -1.93 & 0 & -2.23 & 0 & $\mathrm{C}$ & $\mathrm{CS}$ & $\mathrm{CO}$ & $\begin{array}{l}\text { TP53, SP1, } \\
\text { SMARCA4 }\end{array}$ \\
\hline $\begin{array}{c}\text { keratin 19, type I } \\
(\text { KRT19) }\end{array}$ & 6680606 & $\mathrm{NC}$ & & -1.32 & 0 & -1.84 & 0 & $\mathrm{C}$ & $\mathrm{CS}$ & $\mathrm{CO}$ & OSM, IGFR1, SP1 \\
\hline $\begin{array}{l}\text { myosin, light } \\
\text { chain } 9, \text { regula- } \\
\text { tory (MYL9) }\end{array}$ & 198278553 & -2.59 & 0.0003 & -2.54 & 0.0001 & -2.67 & 0.0017 & $\mathrm{C}$ & $\mathrm{CS}$ & $\mathrm{CO}$ & c-MYC \\
\hline $\begin{array}{l}\text { myosin, heavy } \\
\text { chain } 11, \\
\text { smooth muscle } \\
\text { (MYH11) }\end{array}$ & 241982718 & -1.42 & 0 & -1.52 & 0 & -2.17 & 0 & $\mathrm{C}$ & $\mathrm{CS}$ & $\mathrm{CO}$ & SRF \\
\hline
\end{tabular}


Table 3 (continued). Differentially Expressed Proteins in the Colon Mucosa of Mice Treated with DSS Alone or in Combination with SNE and PE, Identified by QSTAR Elite LC-MS/MS and IPA

\begin{tabular}{|c|c|c|c|c|c|c|c|c|c|c|c|}
\hline $\begin{array}{c}\text { anterior gradient } \\
2 \text { (AGR2) }\end{array}$ & 6753010 & -1.52 & 0 & -1.61 & 0 & -1.91 & 0 & EM & $\mathrm{O}$ & PP & $\begin{array}{c}\text { SMARCA4, } \\
\text { ERBB2 }\end{array}$ \\
\hline $\begin{array}{c}\text { acetyl-CoA } \\
\text { acyltransferase } 2 \\
\text { (ACAA2) }\end{array}$ & 29126205 & -1.21 & 0.0012 & -1.15 & 0.022 & -1.53 & 0 & $\mathrm{C}$ & $\mathrm{E}$ & PP, LM & $\begin{array}{c}\text { PPARA, } \\
\text { PPARGC1A }\end{array}$ \\
\hline $\begin{array}{l}\text { acyl-CoA dehy- } \\
\text { drogenase, C-4 } \\
\text { to C-12 str. chain } \\
\text { (ACADM) }\end{array}$ & 6680618 & $\mathrm{NC}$ & & -1.14 & 0.026 & -1.69 & 0.01 & $\mathrm{C}$ & $\mathrm{E}$ & PP, LM & $\begin{array}{c}\text { PPARA, } \\
\text { PPARGC1A }\end{array}$ \\
\hline
\end{tabular}

1.C: cytoplasm; ES: extracellular space; EPR: endoplasmic reticulum; G: Golgi apparatus; Mi: mitochondria; N: nucleus; P: peroxisome; PM: plasma membrane; 2. E: enzyme; IC, ion channel; K: kinase; Pe: peptidase; Ph: phosphatase; SCR: structural constituent of ribosome; T: transporter; TR: transcriptional regulator; O: other; 3. AP: apoptotic process; CaM: calcium metabolism; CM: cellular migration; CO: cytoskeleton organization; CP: cell proliferation; GM: glutathione metabolism; LM: lipid metabolism; M: metabolism; PP: protein peroxisome proliferation; PS: protein synthesis; OR: oxidation-reduction process; SM: sulfur metabolism; TRA: transcription; XM: xenobiotic metabolism; Ratio: ratio to vehicle control group; NC: no change

Table 4. Up-stream Regulators Affected in DSS Control, SNE and PE Pre-Treated Mice Detected by IPA

\begin{tabular}{|c|c|c|c|c|}
\hline $\begin{array}{l}\text { Up-stream } \\
\text { regulators }\end{array}$ & $\begin{array}{c}3 \% \\
\text { DSS vs } \\
\text { vehicle }\end{array}$ & $\begin{array}{c}3 \% \text { DSS } \\
+ \text { SNE vs } \\
\text { vehicle }\end{array}$ & $\begin{array}{l}3 \% \text { DSS } \\
+ \text { PE vs } \\
\text { vehicle }\end{array}$ & Function \\
\hline NR1/2 (PXR) & 2 & -0.05 & -0.66 & XMS, OR \\
\hline NR1/3 (CAR) & -0.24 & -0.54 & -2.04 & XMS, OR \\
\hline PPARA & -1.76 & -1.48 & -2.33 & PP \\
\hline PPARGC1A & -3.03 & -3.25 & -4.17 & PP \\
\hline PPARGC1B & -1.46 & -2.59 & -1.63 & $\mathrm{PP}$ \\
\hline MYC (c-Myc) & 1.7 & 2.28 & 1.78 & $\mathrm{P}$ \\
\hline MYCN & 4.87 & 4.54 & 4.82 & $\mathrm{P}$ \\
\hline ERBB4 & 2.4 & 1.71 & 1.18 & $\mathrm{P}$ \\
\hline TNF- $\alpha$ & 2 & 1.49 & -0.14 & $\mathrm{P}, \mathrm{A}$ \\
\hline NR3C1 & 2 & $\mathrm{NC}$ & $\mathrm{NC}$ & $\mathrm{P}$ \\
\hline HSF2 & 2.24 & 0.76 & $\mathrm{NC}$ & $\mathrm{P}$ \\
\hline XBP1 & 2.59 & -0.79 & 3.34 & $\mathrm{P}$ \\
\hline PDX1 & 2.14 & 1.09 & 0.71 & $\mathrm{P}$ \\
\hline SMARCA4 & -1.79 & -2.18 & -2.54 & $\mathrm{CCP}$ \\
\hline CREB1 & $\mathrm{NC}$ & -2.71 & 0.4 & $\mathrm{P}$ \\
\hline IGF1R & -1.72 & -3.5 & -1.99 & $\mathrm{P}$ \\
\hline P38 MAPK & $\mathrm{NC}$ & -2.22 & $\mathrm{NC}$ & $\mathrm{P}$ \\
\hline ERK1/2 & $\mathrm{NC}$ & -2.17 & $\mathrm{NC}$ & $\mathrm{P}$ \\
\hline MAP2K1 & $\mathrm{NC}$ & -2.2 & $\mathrm{NC}$ & $\mathrm{P}$ \\
\hline RAF1 & $\mathrm{NC}$ & -2 & -2 & $\mathrm{P}$ \\
\hline PRKG1 & $\mathrm{NC}$ & -2 & $\mathrm{NC}$ & $\mathrm{P}$ \\
\hline PSEN2 & $\mathrm{NC}$ & -2 & $\mathrm{NC}$ & $\mathrm{P}$ \\
\hline TP53 & -3.02 & -3.25 & -2.88 & A \\
\hline SP1 & -2.03 & -2.13 & -1.2 & A, TRA \\
\hline $\mathrm{SRF}$ & -2.34 & -2.78 & -2.68 & $\mathrm{ACO}$ \\
\hline
\end{tabular}

NC: no change; A: apoptosis; ACO: actin cytoskeleton organization; CCP: cell cycle progression; D: differentiation; OR: oxidationreduction process; $\mathrm{P}$ : proliferation; $\mathrm{PP}$ : peroxisome proliferation; TRA: transcription; XMS: xenobiotic metabolism signaling; z-score: <-2.0 regulator significantly inhibited; $>2.0$ regulator significantly activated

greatly and to the less extent SNE, ameliorated these effects, with expected lower levels of ROS generation in mouse colons.

\section{Discussion}

The present study demonstrated a range of changes in clinical symptoms, colonic mucosa histology and pathobiology, cell proliferation, apoptosis and protein expression dependent on the SNE, PE and CF exposure in mice with DSS-induced colitis. The trends for decrease of body weights in DSS-treated mice were observed after 5-7 days of its application. Previously, body weight loss was reported as one of the clinical symptoms of DSS-induced colitis (Baumgart and Sandborn, 2007). On the other hand, DSS-induced significant increase of mouse liver weight, with SNE, PE and CF ameliorating this effect. It is likely that the liver is the main target organ for the extracts because it is the major site of their xenobiotic metabolism (Sturgill and Lambert, 1997).

At the microscopic level, DSS-induced colitis exhibits histological features characterized by edema, ulcer, erosion, inflammatory cell infiltration and crypt loss (Cooper et al., 1993), which were all detected in our study. From our results, SNE, PE, and to a lesser extent CF, caused reduction in the damaged histological appearance of colon mucosa architecture induced by DSS treatment. After injury, wound healing of colonic mucosa consists of several steps including regeneration of crypts through epithelial proliferation and compensation of epithelial monolayer through epithelial cell migration (Tessner et al., 1998). In addition, apoptosis has been reported to be involved in colonic epithelial cell injury (Iwamoto et al., 1996). In this study, DSS administration resulted in the cell cycle arrest and elevated cell death in the colon epithelium. Our results are consistent with those of the previous study report that DSS induces apoptosis and leads to cell cycle arrest in colonic epithelial cells (Araki et al., 2010). These events might further result in destruction of the epithelium barrier, incorporation of intestinal bacteria into the mucosal layer and induction of inflammation (Hans et al., 2000). Importantly, administration of SNE and PE significantly protected colonic epithelium against cell cycle arrest and apoptosis, indicating that they may have suppressive effect on DSS induced colitis by preventing damage to the colonic mucosa.

Next, we focused on protein expression changes which could be related to the preventive effects of SNE and PE on DSS-induced colitis in mice. The pathogenesis of $\mathrm{UC}$ is multifactorial and many aspects remain unclear. Several studies reported that mitochondrial dysfunction may play an important role in the pathogenesis of UC 
(Hsieh et al., 2006; Sifroni et al., 2010). Dysfunction of mitochondria usually leads to reduction in energy supply, increased ROS and induction of apoptotic cell death (Hsieh et al., 2006). The novel finding of the present study was that DSS treatment induced activation of PXR and up-regulated its downstream protein CYP2C9, thus promoting undesirable ROS generation if enzyme induction were not to be reversed (Chen et al., 2004). From IPA analysis, in the colon mucosa of mice with DSS-induced colitis, numerous biological functions, especially those related to the quantity and generation of ROS were altered. We further found that application of SNE and PE ameliorated this effect of DSS. Moreover, proteome analysis indicated that DSS application led to down-regulation of COX5A, which is a subunit of cytochrome c oxidase (complex IV). Previously, Sifroni et al. reported activities of mitochondrial respiratory chain enzymes such as complex II-IV to be decreased in UC patients (Sifroni et al., 2010). Moreover, there are several studies providing evidence of ROS production in UC patients (Nishikawa et al., 2005; Rana et al., 2014) and in chemical-induced colitis using animal models (Damiani et al., 2007). When over-production of ROS occurs in cells, generation of antioxidant enzymes such as superoxide dismutase (SOD), glutathione peroxidase (GPx), catalase (CAT) and increase of levels of glutathione (GSH) are necessary for removal of ROS (Medhi et al., 2008). In DSS-induced colitis, we found down-regulation of GSR, which is related to maintenance of GSH levels. Therefore, it was suggested that down-regulation of COX5A and GSR might impair mitochondria function and lead to increased ROS production during DSS-induced colitis in mice. This is supported by the fact that expression of GSR, and to the lesser extent COX5A, recovered in mice supplemented with SNE and PE, which could be related to improvement of mitochondria function and antioxidant effects.

Abnormalities of mucosal structure or the epithelial barrier are associated with pathological UC. Keratin 8 (KRT8) and keratin 18 (KRT18) are the major cytoskeletal intermediate filaments (IFs) in the intestinal epithelia (Ding et al., 2010). KRT8 is the major type II keratin in the small and large intestine, along with type I keratins KRT18, 19, or 20 dependent on the cell and individual tissue. KRT8 has functional roles in maintenance of normal epithelial architecture (Coulombe and Omary, 2002). Here we observed down-regulation of both KRT8 and KRT18 in mouse colonic mucosa induced by DSS, perhaps as a reflexion of severe damage to the epithelium. Several studies have indicated that KRT8-null mice suffer chronic inflammation (Baribault et al., 1994; Habtezion et al., 2005). Thus, mutation of KRT8 in humans also leads to epithelial instability in the gut and may play a role in IBD (Owens et al., 2004). Furthermore, Treton et al, described changes in protein translation that altered colonic epithelial barrier function involving KRT8, from the results of genome-wide microarray analysis of polysome-bound messenger RNA from UC patients (Treton et al., 2011).

In addition, colon mucosa of mice with DSSinduced colitis may be characterized by lower levels of microfilament-associated proteins tropomyosin 1 and 2
(Tpm1 and Tpm2), which are present in all eukaryotic cells with organ-specific isoforms having distinct functions (Lin et al., 1997). However, this downregulation of Tpm1 and Tpm 2 induced by DSS was also ameliorated in mice administered SNE and PE. It has further been reported that in trinitrobenzenesulphonic acid (TNBS)-induced rat colitis, the Tpm1 gene is down-regulated on day 7 of TNBS treatment (Martinez-Augustin et al., 2008). Therefore, down-regulation of cytoskeleton proteins such as KRTs and Tpms might impair the colonic epithelial structure, allowing bacteria to enter into the lamina propria and trigger mucosa inflammation, as observed in UC. Therefore, maintenance of colonic epithelial structure by SNE and PE clearly might play a role in protection against the strong inflammation which occurs with DSSinduced colitis.

Several reports exist of associations between chronic inflammation and colorectal cancer (Terzic et al., 2010; Rubin et al., 2012). Cytokines that encourage colitisassociated tumor development include TNF, IL-6, and IL-1 while many others were found to be unregulated in these tumor types (Rubin et al., 2012). TNF- $\alpha$ is involved in promotion and progression of experimental and human cancers (Balkwill, 2006). In our IPA upstream regulator analysis, TNF- $\alpha$ was found to be activated in DSS-treated mice. However, amelioration of its activity was observed with SNE and PE, which could be one of the mechanisms of their suppression of inflammation.

Moreover, IPA indicated that oncogenes c-MYC and NMYC were activated but p53 was suppressed in the colonic mucosa of DSS-treated mice. The c-MYC transcription factor is one of the most powerful and frequently deregulated oncoproteins in human cancers. Overexpression of c-MYC has been described in nearly $70 \%$ of colorectal cancers associated with dysplasia of colonocytes in ulcerative colitis (Chu et al., 2007). c-MYC modulates many biological activities including cell proliferation, cell growth and cell transformation. Deregulation observed in the present study could have promoted apoptosis and angiogenesis in line with previous results (Ponzielli et al., 2005). In addition, from our results, the p53 pathway, another important molecular checkpoint, is likely to be suppressed in response to the severe damage to colonic epithelium induced by DSS treatment. In the present model the mechanism of DSS-induced cell death and apoptosis appeared to be independent of p53 activation. In previous studies, an absence or low occurrence of p53 mutations were found during chemically-induced colon tumorigenesis in rodents (De Robertis et al., 2011).

Here we found that administration of SNE or PE prior to DSS impacted on numerous regulators of cell proliferation including NR3C1, HSF2, XBP1, PDX1 and suppressed activity of SMARCA4, CREB1, ERBB4, PHB2, IGF1R, PSEN2, RAF1 and MAP kinases such as p38 MAPK, ERK1/2 and MAP2K1, which could explain their effects on cell proliferation in colonic mucosa. Altogether, the results of proteome and IPA analyses imply that DSS-induced colitis in mice might be associated with colorectal carcinogenesis by regulating inflammatory cytokines, proliferation and apoptosis. Amelioration of 
(A)

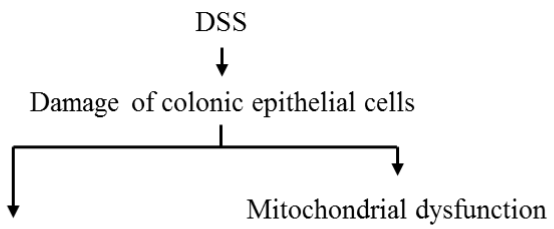

Impaired cytoskeletal structure of colonic epithelial

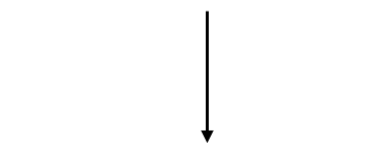

Infiltration of inflammatory cells

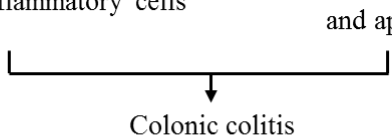

(B)

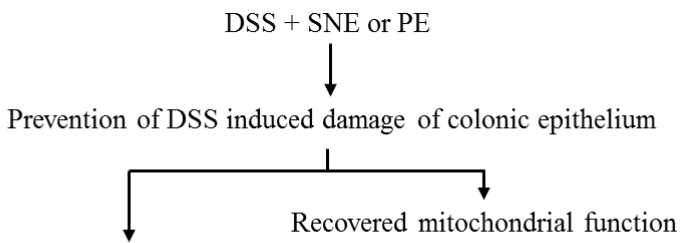

Suppression of destruction of cytoskeletal structure of colonic epithelium

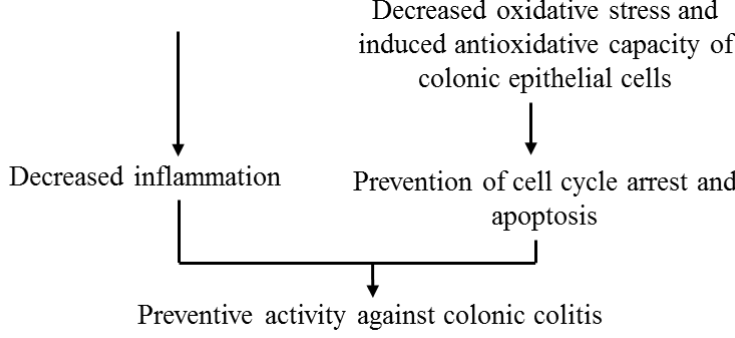

Figure 2. Proposed Mechanisms of DSS-induced Colitis in Mice (A) and the Modifying Efects of SNE and PE (B)

DSS effects on mouse colonic mucosa by pretreatment with SNE and PE could result in prevention of colorectal tumorigenesis.

In conclusion, our results indicated that $\mathrm{SNE}$ and PE exert protective effects against DSS-induced colitis in mice (as illustrated in Figure 2). These effects seem to be related to protection of colonic epithelium from DSSinduced cell cycle arrest and apoptosis, by maintaining normal mitochondrial function and elevating antioxidant levels, finally resulting in improvement of the colonic epithelial architecture.

\section{Acknowledgements}

This study was supported by a grant for a fellowship from the Japanese Association of University Women (JAUW). We are grateful to Rie Onodera, Yuko Hisabayashi and Keiko Sakata for their technical assistance and to Yukiko Iura for her help during preparation of this manuscript.

\section{References}

Araki Y, Mukaisyo K, Sugihara H, et al (2010). Increased apoptosis and decreased proliferation of colonic epithelium in dextran sulfate sodium-induced colitis in mice. Oncol Rep, 24, 869-74.

Ardizzone S, Bianchi Porro G (2005). Biologic therapy for inflammatory bowel disease. Drugs, 65, 2253-86.

Balkwill $\mathrm{F}$ (2006). TNF-alpha in promotion and progression of cancer. Cancer Metastasis Rev, 25, 409-16.

Baribault H, Penner J, Iozzo RV, et al (1994). Colorectal hyperplasia and inflammation in keratin 8-deficient FVB/N mice. Genes Dev, 8, 2964-73.

Baumgart DC, Sandborn WJ (2007). Inflammatory bowel disease: clinical aspects and established and evolving therapies. Lancet, 369, 1641-57.

Chattopadhyay N, Ghosh T, Sinha S, et al (2010). Polysaccharides from Turbinaria conoides: Structural features and antioxidant capacity. Food Chemistry, 118, 823-9.

Chen Y, Ferguson SS, Negishi M, et al (2004). Induction of human CYP2C9 by rifampicin, hyperforin, and phenobarbital is mediated by the pregnane $\mathrm{X}$ receptor. $J$ Pharmacol Exp Ther, 308, 495-501.

Cho EJ, Shin JS, Noh YS, et al (2011). Anti-inflammatory effects of methanol extract of Patrinia scabiosaefolia in mice with ulcerative colitis. J Ethnopharmacol, 136, 428-35.

Chu EC, Chai J, Ahluwalia A, et al (2007). Mesalazine downregulates c-Myc in human colon cancer cells. A key to its chemopreventive action? Aliment Pharmacol Ther, 25, 1443-9.

Cooper HS, Murthy SN, Shah RS, et al (1993). Clinicopathologic study of dextran sulfate sodium experimental murine colitis. Lab Invest, 69, 238-49.

Coulombe PA, Omary MB (2002). 'Hard' and 'soft' principles defining the structure, function and regulation of keratin intermediate filaments. Curr Opin Cell Biol, 14, 110-22.

Damiani CR, Benetton CA, Stoffel C, et al (2007). Oxidative stress and metabolism in animal model of colitis induced by dextran sulfate sodium. J Gastroenterol Hepatol, 22, 1846-51.

De Robertis M, Massi E, Poeta ML, et al (2011). The AOM/DSS murine model for the study of colon carcinogenesis: From pathways to diagnosis and therapy studies. J Carcinog, 10,9.

Ding Y, Lu B, Chen D, et al (2010). Proteomic analysis of colonic mucosa in a rat model of irritable bowel syndrome. Proteomics, 10, 2620-30.

Gluckmann M, Fella K, Waidelich D, et al (2007). Prevalidation of potential protein biomarkers in toxicology using iTRAQ reagent technology. Proteomics, 7, 1564-74.

Habtezion A, Toivola DM, Butcher EC, et al (2005). Keratin8-deficient mice develop chronic spontaneous Th2 colitis amenable to antibiotic treatment. J Cell Sci, 118, 1971-80.

Hans W, Scholmerich J, Gross V, et al (2000). The role of the resident intestinal flora in acute and chronic dextran sulfate sodium-induced colitis in mice. Eur J Gastroenterol Hepatol, 12, 267-73.

Hendrickson BA, Gokhale R, Cho JH (2002). Clinical aspects and pathophysiology of inflammatory bowel disease. Clin Microbiol Rev, 15, 79-94.

Hsieh SY, Shih TC, Yeh CY, et al (2006). Comparative proteomic studies on the pathogenesis of human ulcerative colitis. Proteomics, 6, 5322-31.

Itzkowitz SH, Yio X (2004). Inflammation and cancer IV. Colorectal cancer in inflammatory bowel disease: the role of inflammation. Am J Physiol Gastrointest Liver Physiol, 287, 7-17.

Iwamoto M, Koji T, Makiyama K, et al (1996). Apoptosis of crypt epithelial cells in ulcerative colitis. J Pathol, 180, 152-9.

Kaser A, Zeissig S, Blumberg RS (2010). Inflammatory bowel disease. Annu Rev Immunol, 28, 573-621. 
Kitajima S, Takuma S, Morimoto M (2000). Histological analysis of murine colitis induced by dextran sulfate sodium of different molecular weights. Experimental Animals, 49, 9-15.

Kwon KH, Murakami A, Tanaka T, et al (2005). Dietary rutin, but not its aglycone quercetin, ameliorates dextran sulfate sodium-induced experimental colitis in mice: attenuation of pro-inflammatory gene expression. Biochemical Pharmacol, 69, 395-406.

Lee HJ, Lee HG, Choi KS, et al (2013). Diallyl trisulfide suppresses dextran sodium sulfate-induced mouse colitis: NF-kappaB and STAT3 as potential targets. Biochem Biophys Res Commun, 437, 267-73.

Lin JJ, Warren KS, Wamboldt DD, et al (1997). Tropomyosin isoforms in nonmuscle cells. Int Rev Cytol, 170, 1-38.

Martinez-Augustin O, Merlos M, Zarzuelo A, et al (2008). Disturbances in metabolic, transport and structural genes in experimental colonic inflammation in the rat: a longitudinal genomic analysis. BMC Genomics, 9, 490.

Medhi B, Prakash A, Avti PK, et al (2008). Effect of Manuka honey and sulfasalazine in combination to promote antioxidant defense system in experimentally induced ulcerative colitis model in rats. Indian J Exp Biol, 46, 583-90.

Ngo DH, Kim SK (2013). Sulfated polysaccharides as bioactive agents from marine algae. Int J Biol Macromol, 62, 70-5.

Nishikawa M, Oshitani N, Matsumoto T, et al (2005). Accumulation of mitochondrial DNA mutation with colorectal carcinogenesis in ulcerative colitis. Br J Cancer, 93, 331-7.

Ontawong A, Saowakon N, Vivithanaporn P, et al (2013). Antioxidant and renoprotective effects of Spirogyra neglecta (Hassall) Kutzing extract in experimental type 2 diabetic rats. Biomed Res Int, 2013, 820786.

Owens DW, Wilson NJ, Hill AJ, et al (2004). Human keratin 8 mutations that disturb filament assembly observed in inflammatory bowel disease patients. J Cell Sci, 117, 198999.

Paradossi G, Cavalieri F, Pizzoferrato L, et al (1999). A physico-chemical study on the polysaccharide ulvan from hot water extraction of the macroalga Ulva. Int J Biological Macromolecules, 25, 309-15.

Ponzielli R, Katz S, Barsyte-Lovejoy D, et al (2005). Cancer therapeutics: targeting the dark side of Myc. Eur J Cancer, 41, 2485-501.

Rana SV, Sharma S, Prasad KK, et al (2014). Role of oxidative stress \& antioxidant defence in ulcerative colitis patients from north India. Indian J Med Res, 139, 568-71.

Riezzo I, Turillazzi E, Bello S, et al (2014). Chronic nandrolone administration promotes oxidative stress, induction of proinflammatory cytokine and TNF-alpha mediated apoptosis in the kidneys of CD1 treated mice. Toxicol Appl Pharmacol, 280, 97-106.

Rubin DC, Shaker A, Levin MS (2012). Chronic intestinal inflammation: inflammatory bowel disease and colitisassociated colon cancer. Front Immunol, 3, 107.

Shao P, Chen X, Sun P (2014). Chemical characterization, antioxidant and antitumor activity of sulfated polysaccharide from Sargassum horneri. Carbohydr Polym, 105, 260-9.

Sifroni KG, Damiani CR, Stoffel C, et al (2010). Mitochondrial respiratory chain in the colonic mucosal of patients with ulcerative colitis. Mol Cell Biochem, 342, 111-5.

Song X, Bandow J, Sherman J, et al (2008). iTRAQ experimental design for plasma biomarker discovery. J Proteome Res, 7, 2952-8.

Sturgill MG, Lambert GH (1997). Xenobiotic-induced hepatotoxicity: mechanisms of liver injury and methods of monitoring hepatic function. Clin Chem, 43, 1512-26.

Terzic J, Grivennikov S, Karin E, et al (2010). Inflammation and colon cancer. Gastroenterol, 138, 2101-14.

TessnerTG, Cohn SM, Schloemann S, et al (1998). Prostaglandins prevent decreased epithelial cell proliferation associated with dextran sodium sulfate injury in mice. Gastroenterol, 115, 874-82.

Thumvijit T, Taya S, Punvittayagul C, et al (2014). Cancer chemopreventive effect of Spirogyra neglecta (Hassall) Kutzing on diethylnitrosamine-induced hepatocarcinogenesis in rats. Asian Pac J Cancer Prev, 15, 1611-6.

Thumvijit T, Thuschana W, Amornlerdpison D, et al (2013). Evaluation of hepatic antioxidant capacities of Spirogyra neglecta (Hassall) Kutzing in rats. Interdiscip Toxicol, 6, 152-6.

Treton X, Pedruzzi E, Cazals-Hatem D, et al (2011). Altered endoplasmic reticulum stress affects translation in inactive colon tissue from patients with ulcerative colitis. Gastroenterol, 141, 1024-35.

Wijesekara I, Pangestuti R, Kim SK (2011). Biological activities and potential health benefits of sulfated polysaccharides derived from marine algae. Carbohydrate Polymers, 84, 14-21.

Wirtz S, Neufert C, Weigmann B, et al (2007). Chemically induced mouse models of intestinal inflammation. Nat Protoc, 2, 541-6.

Yousef M, Pichyangkura R, Soodvilai S, et al (2012). Chitosan oligosaccharide as potential therapy of inflammatory bowel disease: Therapeutic efficacy and possible mechanisms of action. Pharmacological Res, 66, 66-79.

Zhao L, Wu H, Zhao A, et al (2014). The in vivo and in vitro study of polysaccharides from a two-herb formula on ulcerative colitis and potential mechanism of action. $J$ Ethnopharmacol, 153, 151-9. 